International Journal of Social Science And Human Research

ISSN(print): 2644-0679, ISSN(online): 2644-0695

Volume 04 Issue 11 November 2021

DOI: 10.47191/ijsshr/v4-i11-01, Impact factor-5.586

Page No: 3063-3074

\title{
Islamic Financial Development between the Volatility of Inflation and the Revival of Economic Growth in the MENA Region
}

\author{
Abderraouf MTIRAOUI ${ }^{1}$, Najoua TALBi ${ }^{2}$ \\ ${ }^{1}$ Ph.D., Teacher at the Private University (UPS- EcoGest)-Sousse- Tunisia \\ ${ }^{2} \mathrm{Ph} . \mathrm{D}$., Director at the Private University (UPS- EcoGest)-Sousse- Tunisia
}

\begin{abstract}
The objective of this article is to study, firsty the direct and indirect effects of Islamic financial development on the variables of economic growth while highlighting the inflastionist situation during the period 2009-2020. Secondy, our empirical contribution is based on the use of simultaneous equation models. Thirdy, we analyze the results found while showing to what extent Islamic financial development remains effective in slowing economic growth when there is an inflationary situation for our MENA study region.
\end{abstract}

KEYWORDS: Islamic Financial Development, Inflastionist Situation, Economic Growth and Simultaneous Equation Model. JEL Classification: $G 29, E 31, O 40, C 33$.

\section{INTRODUCTION}

The international Islamic financial activities are supported by significant issues of Islamic securities such as for example Sukuk securities especially in Europe and Asia as well as by North Africa during the year 2014. These types of issues follow on from growth during the international financial crisis.

Indeed, the emergence of the Islamic securities market is therefore likely to generate lasting structural changes in global financial markets, as it reflects the steps taken by a progressive number of countries to integrate Islamic finance into their investment programs spending to revive economic growth.

Numerous contributions examine the link between the development of the financial system and economic growth, namely the studies of Levine and Zervos (1998) and Beck and Levine $(2004)^{1}$ which tested the relationship between the development of the stock market, the development of the banking sector and economic growth.

However, the main results show that the indicator of banking development is not significantly correlated with economic growth, while the indicator of stock market development is significantly correlated with growth. The results using the ordinary least squares (OLS) method show a strong positive link between stock market development and economic growth and a strong positive link between banking development and growth. ${ }^{2}$.

In this context, the authors argue that the development of banks and stock exchanges has a positive impact on long-term economic growth. Mamun, Basher, Hoque and Ali (2018), examined the role of stock markets in the economic growth of three Asian countries, namely Bangladesh, India and China. They noticed that the stock markets also have a positive relationship with economic growth in all countries ${ }^{3}$.

In addition, Islam offers a financial system based on the principle of sharing profits but also losses, the principle of tangibility through the principle of transparency by rejecting uncertainty, the principle of merit and utility by creating the added value especially in the financing mode, namely " Moudaraba", " Moucharaka", " Mouzaraâ and Moussakat, and ${ }^{4}$...."

\footnotetext{
${ }^{1} \mathrm{~T}$ Beck, R Levine (2004): "Stock markets, banks, and growth: Panel evidence". Journal of Banking

\& Finance, Elsevier.

${ }^{2} \mathrm{Abu}-\mathrm{Bader} \mathrm{S}$. and Abu-Qarn A. S. (2008): "Financial Development and Economic Growth: Empirical Evidence from Six MENA Countries", Review of Development Economics, 12 (4), 803-817.

${ }^{3}$ Mtiraoui, A. and Gabsi, F. (2018): "Finance between Islamic Ethics and Conventional Reality and Economic Growth". Research and Applications in Islamic Finance. ISSN (Online) 2509-0224.Vol. 3, No 1. Pages: $1-20$

${ }^{4}$ Mtiraoui, A. (2020): "Islamic financial development between investment and economic growth in the MENA region and The East Asia and the Pacific". HAL Working Papers; hal-02523154.
} 
Again, Credit-type Financing Modes improve social entrepreneurial activities namely " Morabaha", "Salam", "Ijarah", " Istisnâ" and also Funding Modes based on donations and Charity namely "Zakat", " Waqf", "Credit Without Interest Qard Hasan", and....

However, the diversification of financing methods which can revive economic growth while stabilizing inflation. Fama (1981) supports the idea that the negative relationship between inflation and the prices of financial assets simply reflects the positive relationship between the return on assets and real economic activity.

Moreover, theoretical models of political economy predict that financial policy leads to an inflation situation, for which empirical research is scarce on this subject. Emphasis is placed on the determinants of the level of inflation. Researchers have not yet extensively investigated the causes of inflation volatility.

First, our work deals with an innovative literature review on the interplay between the development of Islamic finance, entrepreneurship and economic growth. Finally, we will empirically study this interaction while showing its direct and indirect effects.

We adopt a methodology called "Channel Methodology" developed by McMillan et al. (2008). This methodology, which is based on a system of simultaneous equations, is used to describe the impact of entrepreneurial activities on various determinants of economic growth and on the Islamic financial indicator.

It will allow to know how Islamic finance stimulates growth for the MENA region during the period (1996 to 2019). This methodology is based on a Simultaneous Equation Model which seeks to describe the impact of Islamic financial development on some determinants of growth in an inflationary situation or in the event of an inflationary trend (case of a trend), the quality of governance, etc.

It clarifies the developmental impact of Islamic finance on growth via inflation for the MENA region during the period (19062019).

\section{LITERATURE REVIEW}

\section{Islamic finance: Alternative to conventional finance?}

Islamic finance is based primarily on the prohibition of interest-bearing loans (Riba) is not in itself a goal to be achieved; nor the one and only peculiarity of Islamic finance. According to its fundamental principle, the ban is only a tool to be able to arrive and apply other principles, that their impact in turn, is more complex, and more explicit towards the economy and growth in general, among these principles, I quote the fight against inflation, and corruption.

Indeed, the authors Chapra (1997), Siddiqui (2004), Khan (1997), Naqvi (1994) and Ahmed (2007) have shown that the Islamic financial system must contribute to the achievement of these objectives of Islam including Chapra (1997) explains that the objectives of the Islamic financial system must be based on the systems of spiritual values and human brotherhood.

These objectives must be in line with the achievement of the objectives of the Shariah Maqassid Sharia. ${ }^{5}$."The purpose of Sharia is to promote the welfare of people, which is to preserve their faith (Din), soul (Nafs), intellect (Al-aql), offspring (Nasl) and property (Māl Anything that guarantees the preservation of these five interests is desirable, and anything that harms them is an evil that must be driven out."6.

When compatible with the Islamic worldview. However, this search for greater material wealth must respect Islamic ethics and be compatible not only with the norms prescribed by the Sharia but above all with the ultimate aims of Maqassid Islam ${ }^{7}$.

The Islamic financial system must respect these ends. Khan (1997) explains that an Islamic financial system must "access the financial means that will enable them to exploit the economic opportunities around them "8.

In our article, the literature will discuss the role of classical finance as a source of economic growth while taking into account the participation of Islamic banks which cannot create credit like conventional banks and also which do not have a interbank market.

In fact, Islamic finance also seems to play a role in economic development through the mobilization of savings. Khan and Mirakhor $(1994)^{9}$ complete this vision by showing that Islamic monetary policy takes place in a framework where all the classic tools, available in a modern economy, are at the disposal of the monetary authorities, with the exception of the discount rate and other tools that involve the use of interest. In addition, the idea of materiality, or the direct link between finance and the real economy, is at the center of Islamic finance.

\footnotetext{
5Muhammad.Al-Gazali (1058-11):"Theologians, jurists, and mystics of Sunni Islam".

${ }^{6}$ Chapra (2000), "The Future of Economics: An Islamic Perspective", The Islamic foundation, Leicester, UK.

${ }^{7}$ Saadallah (2012): "Islamic Finance and developement", Cahier islamic of finance- $N^{\circ} 3$; University

of strasbourg.

${ }^{8}$ T Khan (1997):"Risk management in Islamic banking: A conceptual framework". Islamic Research and Training Institute, Jedda.

${ }^{9}$ Khan and Mirakhor (1994): "Monetary Management In An Islamic Economy"; Journal of Islamic Economics. Vol. 6 .pp: 3-21.
} 
Mair and Marti (2006) ${ }^{10}$ define social entrepreneurship as a process that consists of the innovative use and combination of resources to explore opportunities that represent a catalyst for social change by meeting human needs in a sustainable manner ${ }^{11}$.

To fight against any kind of transaction that does not have an economic interest. We must be based on real and tradable assets (real spheres). Also one of those principles that does not favor Riba and its derivatives representing the prohibition to sell what you do not have. However, "ownership is the main justification for the profit generated either by owning it or selling it. This justification is only a translation of the following rule, since the holding of an asset makes its owner bear risks justifying its profit, if any ${ }^{12}$ "

However, the principles together with that of the prohibition of excessive uncertainty make for example derivatives to be prohibited, but also most important are the procedures which fight against inflation by the eradication of the unreal hits of the product of investment (interest), which proves that this financing philosophy is more effective, with an updated vision and partially linked to the economic circumstances, namely inflation and also economic stagnation.

\section{Growth between stagnaton and inflation: Stagflation}

Among the obstacles to growth, we therefore point out the problem of stagflation, which combines the situation of stagnation and the inflationary situation. Stagflation refers to a condition combining both low economic growth and high inflation.

Economic theory has long considered that this situation could not occur because of the relationship that it assumed to be inverse between growth and inflation: in a phase of cyclical slowdown, economic policy aimed to stimulate activity via the budget deficit while monetary policy eased credit conditions. Growth picked up again at the same time as prices rose. Conversely, if inflation was deemed too high, economic policy became restrictive and monetary policy restricted credit conditions. Activity then slowed down and the rise in prices was contained.

The term "stagflation" was coined in the 1970s to characterize an unprecedented economic situation, when the prices of oil and other commodities soared, caused both an acceleration in inflation and a sharp slowdown growth in industrialized countries.

It was not until the mid-1980s that stagflation ended with the introduction of wage de-indexation policies that helped bring down inflation rates in Western countries.

In France, inflation is measured monthly by INSEE ${ }^{13}$ through the Consumer Price Index (CPI) and the Harmonized Consumer Price Index $(\text { HICP })^{14}$. This latter index, as well as those produced by the various statistical organizations of the member countries of the European Union, is used by Eurostat (a European organization in charge of producing harmonized European statistics) to calculate inflation in the euro zone and in the European Union.

The CPI and the HICP are indicators of the monthly variation of a basket of different products and services representative of final household consumption ${ }^{15}$.

Figure $\mathbf{N}^{\circ}$ 1: Annual variation of the inflation rate in France and the European Union

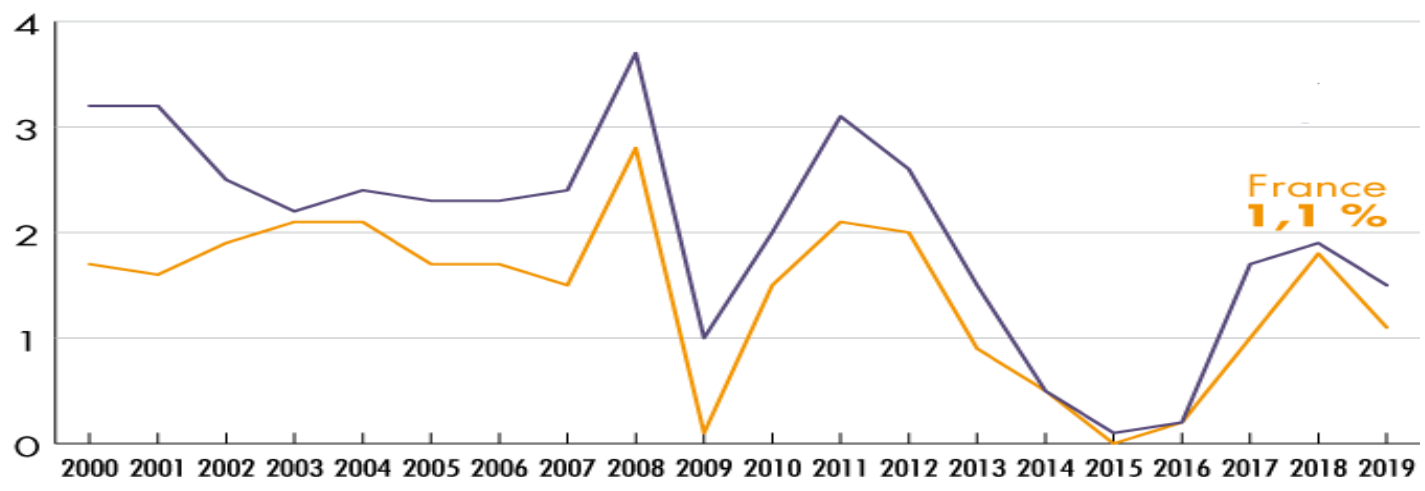

Source: Finance for all.com according to Inesse (Forecast for EU 2019)

\footnotetext{
${ }^{10}$ Mair and Marti (2006):"Social entrepreneurship research: A source of explanation, prediction, and delight". Journal of World Business, 2006, vol. 41, issue 1, 36-44

${ }^{11}$ Abduh, M. et Omar, M. Azmi. (2012): "Islamic banking and economic growth: the Indonesian

experience », International Journal of Islamic and Middle Eastern Finance and Management, Vol.

5, No. 1, pp. 35-47.

12 Wadi MZID (2020): 'Islamic Finance: Fundamentals and Potential Contributions in Financing Growth and Development''. http://rh.banquezitouna.com/upload/1451918489.pdf

${ }^{13}$ National Institute of Statistics and Economic Studies

14 https://www.insee.fr/fr/metadonnees/source/indicateur/p1654/description

15 https://www. lafinancepourtous.com/decryptages/politiques-economiques/theorieseconomiques/inflation/
} 


\section{Relationship between stock prices and inflation}

The thesis of Fama (proxy effect hypothesis) and of Geske and Roll (reverse causality), the rates of return on equities are positively correlated with inflation. Thus, it seems that financial assets, in this case equities, offer at least partial protection against inflation. In addition, equity rates of return are likely to be used by central banks as a source of information on the inflationary expectations of equity market participants.

Fisher states that the nominal rate of return on a financial asset, such as stocks, is equal to the sum of expected inflation and the actual rate of return on the stock. This identity is based on two assumptions. The first relates to the efficiency of the equity market, while the second states that the real rate of return is determined by real factors and that it is therefore independent of inflationary expectations ${ }^{16}$.

Therefore, nominal rates of return on equities can be used by monetary authorities as a leading indicator of inflation.

However, multiple empirical works (Fama, 1981; Geske and Roll, 1983; Kaul, 1987; Kim, 2003) often, four types of models intended to test Fisher's equation reveal a negative relationship between the profitability of values and inflation. This new relationship is referred to in the economic literature as a "stock return-inflation puzzle". A multitude of studies have been devoted to the analysis of this inverse relationship between return on assets and a variety of measures of inflation or expected inflation. The dominant hypothesis to explain this anomaly is the so-called "proxy-effect" hypothesis advanced by Fama (1981) ${ }^{17}$.

Fama (1981) supports the idea that the negative relationship between inflation and the prices of financial assets simply reflects the positive relationship between the return on assets and real economic activity. Since economic activity is negatively correlated with inflation and since stock market profitability is related to economic activity, the negative relationship of profitability and inflation is only a proxy expression of the link between 1 price trends and production variations.

Furthermore, Cecchetti and al. (2003) asserted that taking into account movements in the prices of financial assets in the conduct of monetary policy would result in a better performance of central banks in terms of price stability. In contrast, the work of Bernanke and Gertler $(1999,2001)^{18}$ shows that the gains due to the taking into account of the prices of financial assets on price stability remain very marginal. Thus, from a conceptual point of view, two theses clash. For some, stabilizing the prices of financial assets should be one of the objectives of monetary policy, while opponents consider that these are only one informational element among others that central banks observe. ${ }^{19}$.

\section{ESTIMATION METHODOLOGY}

The literature review emphasizes financial analyzes in relation to economic growth. In this context, we will address the impact of Islamic financial development on economic growth in the event of an inflastionist situation.

\section{Assumptions}

Some authors study the links between the development of finance, inflation and economic growth. Thus, based on the literature, we have formulated the following hypotheses:

$\mathbf{H}_{1}$ : We assume that there is an articulation between the development of Islamic finance (IDF) and economic growth (PDG) in an inflationary situation for MENA countries.

$\mathbf{H}_{2}$ : We admit the existence of a positive relationship between the development of Islamic finance (IDF) and inflation rate to GDP (INFL) which can accelerate economic growth for MENA countries

H3: The inflastionist situation (INFL) is a mediator (intermediary) between finance (IDF) and economic growth (PDG).

\section{Sample, Period and Data ${ }^{20}$}

\section{a. Sample ${ }^{21}$}

Our sample of countries is made up of 9 MENA countries, namely: 4 African countries, 4 Gulf countries and one Mediterranean country. In fact, this study region is made up of 9 countries namely: United Arab Emirates, Qatar, Saudi Arabia, Tunisia, Turkey, Morocco, Egypt, Iran, and Algeria.

\footnotetext{
${ }^{16}$ Fama's idea (1981) is shown the relationship between inflation and prices of financial assets.

${ }^{17}$ Fama (1981):' 'Rendements boursiers, activité réelle, inflation et argent' '. American Economic

Review, vol. 71, numéro 4, 545-65.

${ }^{18}$ Ben S. Bernanke and Mark Gertler (1999): "Monetary policy and asset price volatility".

Economic Review, Federal Reserve Bank of Kansas City, vol. 84 (Q IV), pages 17-51.

${ }^{19}$ Abdelaziz Rouabah (2020): "Inflation and Equity Profitability: An Enigmatic Relationship and a

Headache for Central Banks". 'Economics \& Forecasting 2007/1 (No 177), pages 19 - 34.

20 Mtiraoui, A. and Gabsi, F. (2018): "Finance between Islamic ethics and conventional reality and economic growth in the MENA region"; mpra.ub.uni-muenchen.de/.../1/MPRA paper_88251.

${ }^{21}$ Rym Ayachi Ammar, Mehrez Ben Slama and Dhafer Saidane (2013): "Does the current practice of Islamic banking promote growth?". Studies in Islamic Economics, Vol.6, No 1\&2, p.p. 12
} 
We have formed an international database available in "World Bank CD: WDI" and the word indicator governance "WGI"22.

\section{b. Period}

Depending on data availability, our study period extends from 2006 to 2019 over a period of 14 years.

\section{c. Data}

We introduce three types of variables in our model. First, the economic growth variable "Economic Growth" noted (GDP), dependent variable of the model. We then orient the indicator of the noted early stage inflation rate (INFL). Finally, we introduce a conditional information matrix to control the variables that affect long-term economic growth namely the indicator of Islamic financial development denoted (IDF). We have set up a properly macroeconomic database and the IBIS database. ${ }^{23}$.

\section{Definitions and measures of variables}

\section{a. Indicator of the development of Islamic finance}

To measure financial depth (Depth), King and Levine (1993a, b), Levine and al. (2000), Kpodar (2005) use the M3 aggregate corresponding to the liquid liabilities of the financial system divided by GDP.

In our work, we use the M3 / GDP aggregate provided by the IBIS database for our sample of Islamic banks. This measure is an indicator of the development of Islamic finance and includes the liquid elements of the liabilities of Islamic banks retained.

In their study in 1998, Levine and Zervos add the measurement of the development of the banking sector to cross-sectional studies of growth. According to these authors, this measure is equal to the bank credit of the private sector divided by the GDP denoted IDF (Finis / GDP): Qard Hasan, Mourabahah, Ijarah, Moudarabah, Moucharakah, Salam, Istisna ').

\section{b. Economic Growth Indicator}

- Per capita GDP growth rate:

Levine et al., 2000, Beck et al., 2000, and Beck and Levine, 2004) noted (GDP). Similarly, Mohem and Mairesse (1999, 2001) give some orders of magnitude on the contribution of R\&D to GDP growth.

\section{* Control variables.}

For our work, the ratio of trade value (export + import) / GDP to capture the degree of openness (Sachs and Warver (1995)) noted (TRADE) and the tertiary enrollment rate to control the accumulation of noted human capital (HK).

\section{* Investment.}

Business investment includes gross fixed capital formation (GFCF) and stock change which is seen as a key to growth because it makes human labor more efficient.

The investment, according to the Discovery in 2000 passes quickly on the relationship between investment and growth for the benefit of short-term analysis, the book gives an overview and precise definitions that affects economic growth by improving the efficiency or, indirectly, by increasing the investment resources noted (Inv) (Invest/PIB).

\section{* Foreign direct investment:}

One variable is justified by the abundant literature which states that foreign direct investment has a positive impact on economic growth such as Ikiara, Moses M. (2003) and Fosto, which prove that technology transfers have a positive effect on growth and noted (FDI).

\section{c. Inflation rate indicator}

The World Bank database: «WDI ${ }^{24}$ » estimates this rate against GDP which is used to construct an indicator of the noted inflation rate (INFL).

\section{d. The quality of governance and Political stability}

*Governance quality index (IQG): After calculating the governance quality index. The governance quality index is composed of the capacity for advocacy and expression, (VA), the effectiveness of public action $(\mathbf{G E})$ and the quality of regulations $(\mathbf{R Q})$ by Kaufman D. Kraay A. and Mastruzzi M. (2003) $)^{25}$. The synthetic indicator (IQG) formed following the use of ACP Method ${ }^{26}$. *Political stability noted (PS): IMGs are not used by the World Bank Group to allocate resources. The impact of institutional factors namely political stability noted (PS) and realized

\footnotetext{
22 https://info.worldbank.org/governance/wgi/

${ }^{23}$ http: //www.ibis.online.net

${ }^{24}$ World Development Indicators (WDI) is the World Bank's premier compilation of cross-country comparable data on development. Experience Stories Explore Data.

${ }^{25}$ Kaufman D. Kraay A. and Mastruzzi M. (2003): "Governance Matters III: Governance Indicators for 1996-2002''. https://econpapers.repec.org/paper/wpawuwpma/0308006.htm.

${ }^{26}$ Mtiraoui A.:'' Corruption, institutional quality, human capital and economic growth in the region of mena: the dynamic panel data (GMM)". International Journal of Current Research in Life Sciences. Vol. 4, No. 10, pp. 404-412.
} 


\section{Simultaneous Equation Model}

In order to respond to our basic problem which is that of the direct and indirect impact of the development of Islamic finance (FDI) on economic growth (GDP) in a context of inflation volatility (inflationary situation) noted (INTEA).

*Equation de la Finance Islamique : $F_{i, t}=\delta_{0}+\delta_{1} Y_{i, t}+\delta_{2} I_{i, t}+\sum_{i=3}^{3} \delta_{i} V_{i, t}+\omega_{i, t}$

*Equation de volatilité de l'inflation: $I_{i, t}=\beta_{0}+\beta_{1} Y_{i, t}+\beta_{2} F_{i, t}+\sum_{i=3}^{3} \alpha_{i} P_{i, t}+\mu_{i, t}$

*Equation de la croissance économique : $Y_{i, t}=\alpha_{0}+\alpha_{1} I_{i, t}+\alpha_{2} F_{i, t}+\sum_{i=3}^{5} \alpha_{i} X_{i, t}+\varepsilon_{i, t}$ (C)

With:

$$
\begin{aligned}
& \boldsymbol{Y}_{i, t}=\left(G D P_{i, t}\right) \\
& \boldsymbol{F}_{i, t}=\left(I D F_{i, t}\right) \\
& \boldsymbol{I}_{i, t}=\left(I^{N} \boldsymbol{I L}_{i, t}\right) \\
& \mathrm{X}_{\mathrm{i}, \mathrm{t}}=\left(\mathrm{TRADE}_{i, t}, \mathrm{HK}_{i, t}\right) \\
& \mathbf{P}_{i, t}=\left(\mathrm{FDI}_{i, t}, \mathrm{IQG}_{i, t}\right) \\
& \boldsymbol{V}_{i, t}=\left(\mathrm{INV}_{i, t}, \mathrm{PS}_{i, t}\right)
\end{aligned}
$$

$I F D_{i, t}=\delta_{0}+\delta_{1} G D P_{i, t}+\delta_{2} I N F L_{i, t}+\delta_{3} I N V_{i, t}+\delta_{4} P S_{i, t}+\omega_{i, t}$

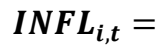

$\beta_{0}+\beta_{1} G D P_{i, t}+\beta_{2} I D F_{i, t}+\beta_{3} F D I_{i, t}+\beta_{4} I Q G_{i, t}+\mu_{i, t} \quad\left(B^{\prime}\right)$

$G D P_{i, t}=\alpha_{0}+\alpha_{1} I N F L_{i, t}+\alpha_{2} I F D_{i, t}+\alpha_{3} T R A D E_{i, t}+\alpha_{4} H K_{i, t}+\varepsilon_{i, t}$

When; $(i=1 \ldots 9 ; N=126 ; t=1 \ldots 14)$

$\boldsymbol{\varepsilon}_{\mathbf{i}, t}, \boldsymbol{\mu}_{\mathbf{i}, \mathrm{t}}$ and $\boldsymbol{\omega}_{\mathbf{i}, \mathbf{t}}$ are respectively the random variables of equations $\mathbf{A}, \mathbf{B}$ and $\mathbf{C}$.

\section{a. Method used: Panel data}

Les Empirical studies have examined very simple models limited to an equation, generally linear where there is an endogenous variable or to be explained. We have assumed $\mathrm{Y}$ which is explained by a set of exogenous variables and a random perturbation (residue). We choose the ordinary least squares method and we then talk about the simultaneous equation model to show the effects of the development of Islamic finance (IDF) on economic growth (GDP) via the noted inflationary situation (INFL). Then the modeling is done by three phases namely:

* Design, that is, writing or specifying the model.

* Estimation of the model's equations, using appropriate techniques.

Two interesting review articles are those of Hausman (1983), who deals with traditional literature, and Phillips (1983), who deals with the more specific field of small-sample theory in models of simultaneous equations, a topic we will not address at all.

\section{* Endogenous problem}

The study of several economic models such as growth, corruption and human capital requires taking into account the problem of endogenity as long as the tested variables interact simultaneously.

Indeed, there are strong reciprocal causalities between these factors, which brings us back to the problems of endogenity and simultaneity. The estimation methods that can be used in this context of simultaneous equation models depend on the identification criteria of the model to be estimated and the endogenous problem.

\section{* REG3 Method (Three-stage least-squares regression)}

In our case, the model presented is over-identified. The econometric method adopted was the REG3 method (Three-stage leastsquares regression). This method is suitable for dealing with this kind of model.

Indeed, the REG3 estimation method is based on the principle of applying the ordinary least squares method in three steps. One technique for solving endogeneity problems is to introduce the variables that cause these problems as instrumental variables.

However, the version used in our study is that of STATA 15.1. Using the SLS 3 method, processing with the Stata software allows us to fully resolve the results to be criticized.

\section{b. Preliminary tests}

\section{* Stationarity tests}

We know in advance that to verify the stationarity of panel data, we can use 1st generation stationarity tests. These types of 1 st generation tests affecting panel data are the tests of Levin and Lin (1992); Pesaran (1997); and K. Hadri (2000). This being the case, it is important to point out that for the first generation tests, they are only applicable on the balanced panels, that is to say without missing data, as is the case for our variables.

So using the Pesaran test (1997), we find that all the variables used are all stationary in level. 


\section{* Collinearity study between the independent variables:}

We assume, in this work, that the bias due to this problem is zero. The second difficulty arises when there is a strong correlation between the explanatory variables. A strong correlation leads to poor estimates of the coefficients because the determinant of the matrix ( $\mathbf{X X}$ ') will be almost equal to zero; with $(\mathbf{X})$ : the matrix of explanatory variables.

* Multicolinearity problem and model selection:

- Principle: The explanatory variables are highly correlated with the explained variable. They must be weakly correlated with each other;

- Consequences of multicollinearity: Among the consequences existing in this framework, it is the increase in the estimated variance of certain coefficients and also the instability of the estimators of the least squares coefficients. Therefore, in the case of perfect multicollinearity, the matrix $\left(\mathbf{X}^{\prime} \mathbf{X}\right)$ is singular, the estimation of the coefficients is then impossible;

- Klein's test: This is not a statistical test in the sense of a test of hypotheses but simply a criterion of presumption of multicollinearity. There is an appearance of multicollinearity if the coefficient of determination of the complete model ( $\mathbf{R}^{2}$ ) is less than the correlation coefficients $\left(\mathbf{r}_{\mathbf{2}} \mathbf{x}, \mathbf{x j}\right)$ and we have to compare the $\mathbf{R}$ to the correlation coefficients $\left(\mathbf{r}_{\mathbf{x}} \mathbf{i} \mathbf{x j}\right)$ which appear in the coefficient matrix correlation;

- To correct the regression chain: this is a purely numerical response which consists in transforming $\mathbf{X}^{\prime} \mathbf{X}$ into $\left(\mathbf{X}^{\prime} \mathbf{X}+\boldsymbol{\alpha I}\right)$ where $\alpha$ is a constant chosen arbitrarily. We thus increase the first diagonal and the "numerical" effects of multicollinearity are reduced.

- Other methods: The first method is step-by-step regression which procedure is identical to the previous one, except that after the incorporation of a new explanatory variable, the Student's t of each of the previously selected explanatory variables are examined and the variables whose Student's t is less than the critical threshold are eliminated.

The second method is the regression by stage which process of selection of the explanatory variables allowing to minimize the inters correlations between the explanatory series by study of the residual:

- Problem of identification of the equations of the model: the conditions of identification of a model are determined equation by equation. Three scenarios can arise.

- The model is under-identified, if an equation in the model is under-identifiable (ie there are fewer equations than parameters to be identified in the structural form). In such a situation, the system is impossible to solve.

- The identified model, when all the equations are identifiable "correct".

- The model is over-identified, if the equations of the model are either identifiable "correct" or over-identifiable.

When the model is under-identified, it is impossible to estimate its parameters and the modeling must be re-specified. The conditions for identifying a model are the subject of a sometimes complex development... .

\section{- Exclusion restrictions}

In our model, the variable "IDF" appears at the level of the third equation as an endogenous variable and, respectively, at the level of the second and the first equation as an exogenous variable. Likewise, the variables "GDP" and "INFL" appear at the level of the last equation as exogenous variables and inflation INFL appears at the level of the second equation as an endogenous variable and GDP appears at the level of the first equation as an endogenous variable.

\section{* The necessary conditions: Order conditions ${ }^{27}$}

In our case, we note for the model to be studied, that all the equations are over-identified. Indeed, we have three endogenous variables in the model (ie $\mathbf{W}=\mathbf{3}$ ) "GDP", “INFL" and "IDF" and five exogenous variables: "TRADE", "HK" "INV", "FDI", "PS “.

- The first equation has seven exclusion restrictions and no constraint restrictions Applying the identification conditions, the variables appearing in the human capital equation give: $\mathbf{W}^{\prime}=\mathbf{1}, \mathbf{K}^{\prime}=\mathbf{5}$ and $\mathrm{r}=0$ with $\mathbf{W}^{\prime}$ is the number of endogenous variables appearing in an equation and $K^{\prime}$ is the number of exogenous variables in an equation. Let therefore: $\mathbf{W}-\mathbf{W} '+\mathbf{K}-\mathbf{K}^{\prime}=\mathbf{3}-\mathbf{1}+\mathbf{8}-$ $\mathbf{5}=\mathbf{5}>\mathbf{W}-\mathbf{1}=\mathbf{3}-\mathbf{1}=\mathbf{2}$, the first equation is therefore over-identified.

- The second equation has seven exclusion restrictions but no constraint restrictions. We therefore have: $\mathbf{W}=\mathbf{3}, \mathbf{K}=\mathbf{8}, \mathbf{W} '=\mathbf{1}, \mathbf{K}$ ' $=\mathbf{3}$ and $\mathrm{r}=0$, which gives us: $\mathbf{W}-\mathbf{W}^{\prime}+\mathbf{K}-\mathbf{K}^{\prime}=\mathbf{3}-\mathbf{1}+\mathbf{8}-\mathbf{3}=\mathbf{7}>\mathbf{W}-\mathbf{1}=\mathbf{2}$, the second equation is therefore over-identified

- The third equation has six exclusion restrictions but no constraint restrictions.

So we have $\mathbf{W}=\mathbf{3}, K=\mathbf{8}, W^{\prime}=\mathbf{1}, K^{\prime}=\mathbf{4}$ and $r=0$, which implies $W-W^{\prime}+K-K^{\prime}=\mathbf{3}-\mathbf{1}+\mathbf{8}-\mathbf{4}=\mathbf{6}>\mathbf{W}-\mathbf{1}=\mathbf{2}$, the third equation is therefore over-identified. Since in our model all the equations are over-identified, the model will therefore be overidentified.

27 When the model has linear restrictions, we have to add their number in the second part of the equality so we have to compare $\boldsymbol{w}-\mathbf{1}$ and $\boldsymbol{w}-\boldsymbol{w}+\boldsymbol{K}-\boldsymbol{K}^{\prime}+\boldsymbol{r}$. 
Islamic Financial Development between the Volatility of Inflation and the Revival of Economic Growth in the MENA Region

IV. ANALYSIS, PRESENTATIONS OF RESULTS AND COMMENTS

1. Descriptive analyzes

a. Descriptive measures

* The average: allows to identify the value of the observations distributed.

* The standard deviation: allows you to determine the fluctuations of observations around the arithmetic mean.

* The coefficient of variation: allows you to gauge what the average is worth with regard to all the observations.

Table $N^{\circ}$ 1: Descriptive statistics for the MENA region

\begin{tabular}{|l|l|l|l|l|l|}
\hline Variable & Obs. & Mean & Std. Dev. & Min. & Max. \\
\hline GDP & 126 & 5.207289 & 3.984583 & -5.697477 & 20.84316 \\
\hline INFL & 126 & .0909642 & .1026885 & .0000578 & .843085 \\
\hline IDF & 126 & .1003977 & .1844775 & .0039981 & .9985433 \\
\hline FDI & 126 & 2.460149 & 2.282044 & -.9982212 & 9.678341 \\
\hline INV & 126 & 2.422588 & 6.150167 & .1688623 & 23.55618 \\
\hline HK & 126 & 24.35598 & 12.67582 & 6.09751 & 60.6836 \\
\hline TRADE & 126 & 6.315249 & 15.75779 & .3901794 & 57.995 \\
\hline IQG & 126 & .5510141 & .1768773 & .2138891 & .8733797 \\
\hline PS & 126 & .5319487 & .0747535 & .3214541 & .6666667 \\
\hline
\end{tabular}

Source: The output of Stata15.1 made by the authors

b. Matrix tables

Table $\mathbf{N}^{\circ}$ 2: Correlation matrix between variables for the MENA region

\begin{tabular}{|l|l|l|l|l|l|l|l|l|l|}
\hline & GDP & INFL & IDF & FDI & INV & HK & TRADE & IQG & PS \\
\hline GDP & 1.000 & & & & & & & & \\
\hline INFL & 0.247 & 1.000 & & & & & & & \\
\hline IDF & -0.101 & -0.118 & 1.000 & & & & & & \\
\hline FDI & 0.299 & 0.009 & -0.022 & 1.000 & & & & & \\
\hline INV & -0.0467 & -0.136 & -0.163 & -0.111 & 1.000 & & & & \\
\hline HK & -0.183 & 0.116 & -0.385 & -0.052 & 0.464 & 1.000 & & & \\
\hline TRADE & -0.086 & -0.147 & -0.155 & -0.109 & 0.6911 & 0.469 & 1.000 & & \\
\hline IQG & 0.045 & 0.293 & -0.329 & -0.201 & 0.175 & 0.159 & 0.171 & 1.000 & \\
\hline PS & 0.251 & 0.423 & 0.066 & 0.067 & 0.256 & 0.237 & 0.260 & 0.355 & 1.000 \\
\hline
\end{tabular}

Source: The output of Stata15.1 made by the authors

2. Presentation and discussion of the results

a. Presentation of results

Table $\mathrm{N}^{\circ}$ 03: Analysis of the results of the simultaneous equation model Reg3

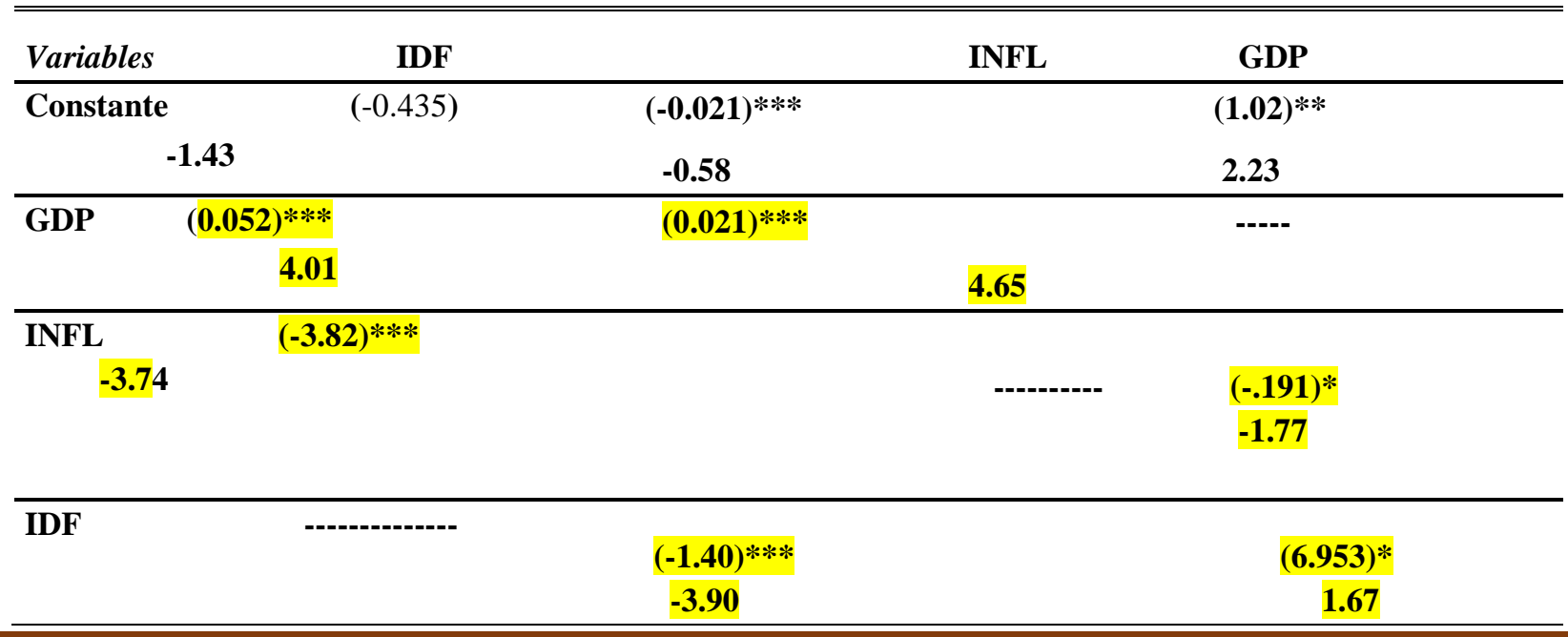


Islamic Financial Development between the Volatility of Inflation and the Revival of Economic Growth in the MENA Region

\begin{tabular}{|c|c|c|c|c|}
\hline FDI & --.---.--- & & $\begin{array}{c}(0.0007) \\
0.22\end{array}$ & --.---.- \\
\hline INV & $(-0.009)$ & & ------------ & ---------.- \\
\hline HK & --------- & & ---------- & $\begin{array}{r}(-0.028) \\
-0.76\end{array}$ \\
\hline TRADE & --------- & & ------------- & $\begin{array}{r}(0.0101) \\
0.48\end{array}$ \\
\hline IQG & ------- & & $\begin{array}{c}(0.034) \\
0.68\end{array}$ & ------- \\
\hline PS & $\begin{array}{l}1.191 \\
1.55\end{array}$ & & ------------ & -------- \\
\hline Obs. & 126 & & 126 & 126 \\
\hline Prob. & 0.000 & 0.000 & & 0.000 \\
\hline$R^{2}$ & 0.28 & 0.3 & & 0.45 \\
\hline
\end{tabular}

Source: The output of Stata15.1 made by the authors

Note: The terms in parentheses correspond to T-Student and ***, **, *: significant at a threshold of 1\%, 5\% and 10\% respectively.

\section{b. Discussion of results}

We can recall that the aim of this paper is to test the impact of Islamic financial development (IDF) on economic growth (GDP) in an inflationary situation (INFL) for some countries of the MENA region. Otherwise, we clarify "the interaction between Islamic Financial Development (IDF), Inflation (INFL) and Growth (GDP) for the MENA region" while showing the direct and indirect effects of Islamic Financial Development (IDF) on growth ( GDP) and on the other variables via the inflationary situation (INFL) by applying a model to simultaneous equations over the period from (2006-2019).

According to the results found, the first equation $\left(\mathbf{A}^{\prime}\right)$ of the model shows that inflation (INFL) as an endogenous element to be explained and which plays a primordial role in growth, can explain the nature of the relationship between Islamic Financial Development (IDF) and macroeconomic variables. In fact, the growth rate per capita (GDP) has a positive (0.0524) and significant effect at $1 \%$ on Islamic financial development (IDF). So when the growth rate increases $1 \%$ it will have a positive evolution 4 points for the Islamic Financial Development (IDF) indicator.

Moreover, this significant and positive relationship between the two variables is confirmed in the last equation $\left(\mathbf{C}^{\prime}\right)$ as a reciprocal relationship since the increase in Islamic financial development (IDF) by $\mathbf{1 0 \%}$ favors an increase in Economic growth $\mathbf{7}$ points of the initial situation. This implies that the indicator (IDF) is a catalyst for growth (GDP) in this region and MENA and Asia Pacific. In this context, Patrick Imam, Kangni Kpodar $(2015)^{28}$ assert "that it emerges that despite its relatively modest size compared to all economic activities and the financial system, the development of Islamic finance is correlated positively with economic growth, even controlling for the effect of various determinants of growth, such as the depth of the financial sector. The results of our analysis are robust to changes in specifications, samples and time periods. "

In addition, the estimation of the model in the first level (A') shows that there is a significant $\mathbf{1 \%}$ negative (-3.820196) between Islamic financial development (IDF) and inflation (INFL) reflects a decrease in Islamic financial development (IDF) almost 4 points when inflation (INFL) increases by $\mathbf{1 \%}$. This result is fully confirmed in the second equation (B') in a reciprocal articulation between inflation and the development of Islamic finance (IDF). Likewise, the negative indirect articulation $(\mathbf{- 3 . 8 2} * \mathbf{3 5 . 7 5})$ between the development of Islamic finance (IDF) and economic growth (GDP) via inflation (INFL) is significant at $(\mathbf{1 \%} * \mathbf{1 \%})$ and vice versa. the negative indirect link $(\mathbf{- 3 . 8 2} * \mathbf{0 . 2 1})$ between GDP and IDF through INFL is significant $(\mathbf{1 \%} * \mathbf{1 \%})$. The inflastionnist situation (INFL) has a detrimental effect on the development of Islamic finance which conforms to the work Fama (1981) supports the idea that the negative relationship between inflation and the prices of financial assets simply reflects the positive relationship between the return on assets and real economic activity.

\footnotetext{
${ }^{28}$ Patrick Imam and Kangni Kpodar (2015): “Islamic Finance and Economic Growth: An Empirical Analysis”. Development Economics Journal (Vol. 23), pp. 59-95.
} 

Region

Regarding regression $\mathbf{N}^{\circ} \mathbf{1}$ of our Simmultyear Equation Model, the investment (INV) has a negative (-0.009) and insignificant impact on the indicator of the development of Islamic finance (IDF) of equation (A '). This relationship essentially depends on the indicator of political stability (PS) has a positive impact (1.191) and not significant on the development of Islamic finance (IDF) therefore political instability encourages. The inflationary situation (INFL) and the parallel economy. In this sense, the estimation of equation (B) results that the indicator of governance quality (IQG) is positively colored (0.0344) and not significant with the inflation indicator (INFL). Thus, the quality of governance (IQG) has an indirect impact correlated positively $(\mathbf{0 . 0 3 4 4} * \mathbf{3 5 . 7 5})$ and statistically not significant with growth (GDP). However, multiple empirical works (Fama, 1981; Geske and Roll, 1983; Kaul, 1987; Kim, 2003) often, four types of models intended to test Fisher's equation reveal a negative relationship between the profitability of values and the 'inflation. This result confirms the importance of the quality of governance among one of the determinants of economic growth (GDP) to stabilize inflation so that this quality of governance becomes attractive to FDI and also human capital (HK) becomes competitive and secure qualified that was not clarified in the estimation of equation (B) and in the estimation of equation (C).

In total, it is therefore necessary to mention that the inflastionist situation a key element to orient the majority of economic activities and also target these financial activities to stimulate the growth of GDP per capita in our study region (MENA).

\section{CONCLUSION}

To answer certain questions linked to the empirical results reported in the new literature. This work emphasizes the evaluation of the role of one of the economic indicators namely inflation in determining the economic circuit which clarifies the nature of the relationship between Islamic finance and economic growth in the MENA region during a period well determined.

Indeed, the analysis presented takes as an example the MENA region is made up of 9 countries during the period from 2006 to 2019. According to the main results of this article, we first point out that the inflationary or deinflationary situation remains a mandatory condition for the development of Islamic finance to improve and stimulate economic growth in a context of political stability and good governance. Then, we showed that these conditions can attract FDI and improve human skills and develop investment (infrastructure) and the degree of trade openness.

Then, their degree of political stability. However, the structural factors identified in the literature as complementary to FDI (trade openness, infrastructure spending, human capital, etc.) are generally those that are mobilized in attractiveness policies. Microeconomic incentive policies which often constitute the heart of attractiveness policies are therefore socially optimal only if they intervene at an already advanced stage of the structural development of an economy, or if they are integrated into broader strategies, aiming to develop in parallel all the factors which are complementary to FDI in determining growth.

While they do not generate carry-over effects on the economy as a whole thanks to the complementarities described in this article, they only generate an additional growth of the extensive type and strongly reversible in the case where productive capital falls would relocate elsewhere.

The policy of attractiveness cannot therefore replace a long-term development strategy, any more than sustainable growth can be supported by foreign investments alone, especially in the presence of Islamic financial development.

\section{BIBLIOGRAPHY}

1) Abu-Bader S. and Abu-Qarn A. S. (2008): "Financial Development and Economic Growth: Empirical Evidence from Six MENA Countries", Review of Development Economics, 12(4), 803-817.

2) Abdelaziz Rouabah (2020): "Inflation and Equity Profitability: An Enigmatic Relationship and a Headache for Central Banks". 'Economics \& Forecasting 2007/1 (No 177), pages 19 - 34.

3) Beck and Levine (2004): "Stock markets, banks, and growth: Panel evidence". Journal of Banking \& Finance, Elsevier.

4) Ben S. Bernanke and Mark Gertler (1999): "Monetary policy and asset price volatility". Economic Review, Federal Reserve Bank of Kansas City, vol. 84(Q IV), pages 17-51.

5) Abu-Bader S. and Abu-Qarn A. S. (2008): "Financial Development and Economic Growth: Empirical Evidence from Six MENA Countries", Review of Development Economics, 12 (4), 803-817.

6) Ahmed. H., (2004): "Role of Zakah and Awqaf in Poverty Alleviation", Occasional Paper No. 8, Islamic Research and Training Institute, Islamic Development Bank, Jeddah.

7) Attia. M., (2011): "Islamic Approaches to Development: A case study of Zakat, Sadaqa and Qurd al Hassan in Contemporary Egypt", 8th International Conference on Islamic Economics and Finance..

8) Dhareer, Siddiq al, (1997): "Al-Gharar in Contracts and its Effects on Contemporary Transactions", Jeddah: Islamic Research and Training Institute.

9) Chatti Mohamed Ali (2010) : “Analyse comparative entre la finance islamique et le capital-risque ", Etudes en économie islamique Vol.4, $\mathrm{N}^{\circ} .1$. 
10) Ebrahim, M.S. (2009): «Can an Islamic model of housing finance cooperative elevate the economic status of the underprivileged ? », Journal of Economic Behavior \& Organization 72, pp. 864-883.

11) Fama (1981):'"Rendements boursiers, activité réelle, inflation et argent'. American Economic Review, vol. 71, numéro 4, $545-65$.

12) Iqbal, M. and Khan, M. F. (1981): “A Survey of Issues and a Programme for Research in Monetary and Fiscal Economics of Islam", International Research in Islamic Economics.

13) Khan (1997):"Risk management in Islamic banking: A conceptual framework". Islamic Research and Training Institute, Jedda.

14) Kaufmann, D.A., Kraay, A., Mastruzzi, M., (2005): “Governance matters Governanc indicators for 1996.2004". Working paper. The World Bank, Washington, DC.

15) King and Levine (1993a): "Finance and Growth: Schumpeter Might Be Right."' Quarterly Journal of Economics. The MIT Press, Vol. 108, No. 3, pp. 717-37.

16) Levine, R., N. Loayza and T. Beck (2000): "Financial Intermediation and Growth: Causality and Causes ', Journal of Monetary Economics, 46: 31-77.

17) Majid, S.A. and Kassim, S. (2010): "Islamic finance and economic growth: The Malaysian experience”, In: Kuala Lumpur Islamic Finance Forum, Kuala Lumpur, 2-5 August 20

18) M. Tabash and Raj S. Dhankar (2014): "The flow of Islamic finance and economic growth: An empirical evidence of Middle East". Journal of Finance and Accounting. Vol. 2, No. 1, pp. 11-19. Doi: 10.11648/j.jfa.20140201.12.

19) Mtiraoui A. and. Lassoued M. (2019): "Interaction Entre La Finance Islamique, La Gouvernance Et La Croissance économique Dans La Région Mena Et L'Asie Pacifique '. Revue Etudes en Economie et Commerce et Finance. Vol. 7, $\mathrm{N}^{\circ} .1$, Pages 1069-1103

20) Mtiraoui and Gabsi, (2018): "Finance between Islamic ethics and economic growth in the MENA region". Researches and Applications in Islamic Finance; Vol. 3, $\mathrm{N}^{\circ}$ 1, p.p: 1-20.

21) Mtiraoui, A. (2020): "Islamic financial development between investment and economic growth in the MENA region and The East Asia and the Pacific". HAL Working Papers; hal-02523154

22) Peredo, Ana María, and Murdith McLean (2006): "Social entrepreneurship: A critical review of the concept". Journal of World Business 41, $\mathrm{N}^{\circ} 1$, p.p: 56-65.

23) Rym Ayachi Ammar, Mehrez Ben Slama and Dhafer Saidane (2013) : " La pratique actuelle des banques islamiques favorise-t-elle la croissance? “. Etudes en Economie Islamique, Vol.6, No 1\&2,p.p. 12

24) Saadallah (2012): "Islamic Finance and developement", Cahier islamic of finance- $N^{\circ} 3$; University of strasbourg.

25) Saffari, S. (1995): "Islamic banking in theory and practice “, Centre of Middle Eastern Studies working paper, Havard University.

\section{APPENDICES}

\section{Appendice 1: The method of calculating the indicator measuring Islamic bank loans (Laurent, 2014)}

To calculate the indicator measuring Islamic bank loans, we will follow the approach proposed by (Laurent, 2008) in his thesis entitled "The Influence of Culture on Economic Outcomes: An Exploration of Islamic Finance as a New Transmission Channel". Step 1: Calculation of the share of Islamic banking assets (or deposits) that measures the penetration rate of Islamic banks in the total banking system. The Islamic asset penetration for a country $\mathbf{i}$ is Calculated as follows:

$$
I F_{\text {pend. }}(\text { the assets })_{i}=\frac{{\text { Asset }(I F)_{i}}_{\text {The assets }(\text { Total })_{i}}}{\text { The }}
$$

With, Asset (IF) $)_{\mathrm{i}}$ the total of Islamic bank assets in US dollars for a country $\mathrm{i}$ and Te assets(Total) $)_{i}$ is the total of banking assets (Islamic and conventional) in US dollars for the same country i. The penetration rate of Islamic bank deposits is calculated in the same way:

$$
I F_{\text {pend } .}(\operatorname{deposits})_{i}=\frac{\operatorname{deposits}(I F)_{i}}{\operatorname{deposits}(\text { Total })_{i}}
$$

With, deposits $(\boldsymbol{I F})_{i}$ the total Islamic bank deposits in US Dollars for a country $\mathbf{i}$ and $\operatorname{deposits}(\text { Total })_{i}$ total bank deposits (Islamic and conventional) in US dollars for the same country i.

Step 2: The overall penetration rate of Islamic banks. We define the overall penetration of Islamic banks in the financial system by means between the last two ratios ((1) and (2)):

$$
I F_{P_{\text {Pend }}}=\frac{I F_{P e n}(\text { Asset })_{i}+I F\left(\text { deposits }_{i}\right.}{G D P_{i}}
$$

Step 3: We can calculate the indicator of the size of the private Islamic credits (deposit) relating to the domestic economy. We first calculate the private credits of Islamic banks: With the private credits of Islamic banks, penetration rate of Islamic banking assets and the total of private credits (Islamic and conventional). Finally, the ratio of total credit granted to private enterprises by Islamic banks to GDP is: $\boldsymbol{C P}(\boldsymbol{I F})_{i}=\boldsymbol{I} \boldsymbol{F}_{\text {pend. }}(\boldsymbol{A c t i f s})_{i} * \boldsymbol{C P}(\text { Total })_{i}$ 
Islamic Financial Development between the Volatility of Inflation and the Revival of Economic Growth in the MENA Region

With, $\boldsymbol{C P}(\boldsymbol{I F})_{i}$ private loans from Islamic banks, $\boldsymbol{I F}_{\text {pend. }}(\boldsymbol{A s s e t s})_{i}$ penetration rate of

Islamic banking assets and $\boldsymbol{C P}(\boldsymbol{T o t a l})_{i}$ the total of private credits (Islamic and conventional). Finally, the ratio of total credit granted to private enterprises by Islamic banks to GDP is:

$$
C P / G D P(I F)_{i}=\frac{C P(I F)_{i}}{G D P_{i}}
$$

